\title{
Profitability Analysis of Domain to Host
}

\author{
CS Gowtham Chakravarthy, S. Praveen Kumar
}

\begin{abstract}
This study is conducted to analyze the profitability analysis of Domain to Host. The aim of the study is to learn about the effectiveness and performance of the Company, to suggest measures for the improvement of the company, to know the position of company in the market, to know whether the company is in a profitable position, to calculate the future trends and profits of the company using trend analysis and to know the profitability of the company by comparing the current year balance sheet with previous year using comparative analysis. The data of the past 5 years are taken into account for study. The performance is compared within those periods. This study finds out the areas where the Domain to Host can improve to increase the efficiency of its assets and funds employed. The scope of the study involves factors that financial efficiency of the Company. To increase profit and sales growth of the company. This study finds out the operational efficiency of the organization and allocation of the resources to improve the efficiency of the organization.
\end{abstract}

Keywords: Efficiency, Analysis, Assets

\section{INTRODUCTION}

\section{A. Meaning Of Financial Statements}

Fiscal summaries allude to such proclamations which contains financial information about a venture. They report benefit and the money related position of the business toward the finish of bookkeeping period[1],[3],[5]. The group fiscal report incorporates at any rate two articulations which the bookkeeper plans toward the finish of a bookkeeping period. The two articulations are: -

\section{The Balance Sheet}

\section{2.Profit And Loss Account}

They give some incredibly helpful data to the degree that monetary record reflects the money related position on a specific date regarding the structure of advantages, liabilities and proprietors value, etc and the Profit And Loss record demonstrates the consequences of activities during a specific timeframe as far as the incomes got and the expense caused during the year. Along these lines the fiscal summary gives a condensed perspective on money related positions and tasks of a firm[2],[4],[6] .
Revised Manuscript Received on July 22, 2019.

Mr. CS Gowtham Chakravarthy, Department of MBA, Bharath Institute of Higher Education and Research, Chennai, India.

Email: chakravins@gmail.com

Dr. S. Praveen Kumar, Department of MBA, Bharath Institute of Higher Education and Research, Chennai, India.

Email: praveenkumar.mba@bharathuniv.ac.in

\section{B. Meaning Of Financial Analysis}

The principal errand of budgetary investigation is to choose the data important to thedecision under thought to the all out data contained in thefinancial articulation. The subsequent advance is to organize the data in a manner to feature critical relationship. The last advance is translation and reaching of surmising and determinations. Fiscal summary is the procedure of choice, connection and assessment.

\section{C.Features Of Financial Analysis}

- To present a mind boggling information contained in the budget report in straightforward and reasonable structure.

- To characterize the things contained in the budget report in advantageous and reasonable gatherings[7],[9],[11].

- To make examination between different gatherings to reach different inferences.

\section{Purpose Of Analysis Of Financial Statements}

- To know the acquiring limit or benefit.

- To know the dissolvability.

- To know the budgetary qualities.

- To know the capacity of installment of intrigue and profits[8],[10],[12].

- To make near examination with different firms.

- To know the pattern of business.

\section{DATA ANALYSIS AND INTERPRETATION}

Table - 1 Current Ratio: Current Asset/Current Liabilities

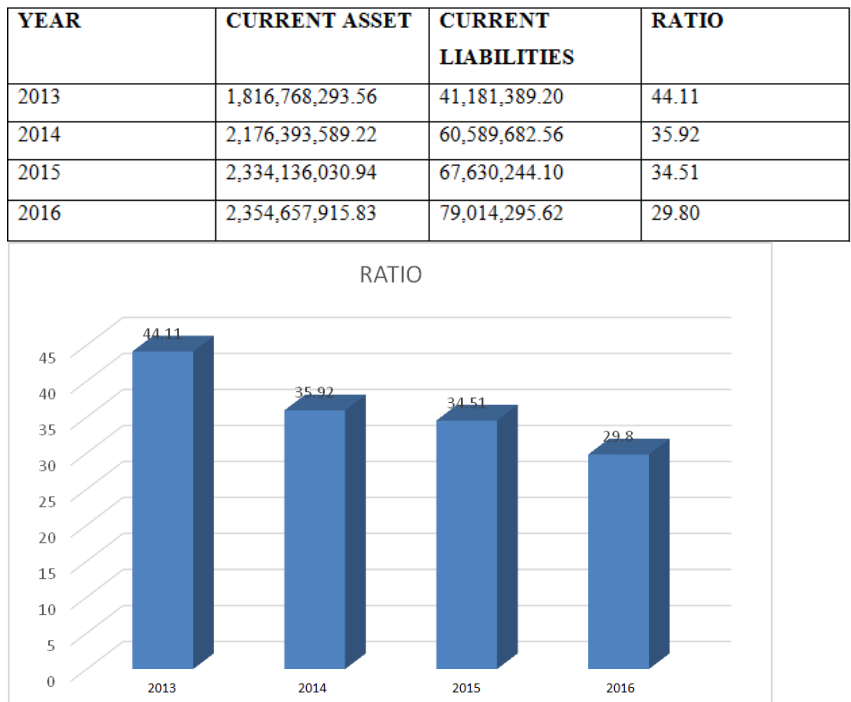

\section{Interpretation:}

The above table shows that the current ratio. The highest current ratio is 44.11 in the 


\section{Profitability Analysis of Domain To Host}

year of 2013.Then the ratio is decreased in the year of 2014, the ratio value is 35.92 . The third highest ratio value is 34.51 in the year of 2015 . Finally the last year ratio value is 29.80 .

Table -2 Quick Ratio=Quick Asset/Current Liabilities

\begin{tabular}{|l|l|l|l|}
\hline YEAR & QUICK ASSES & $\begin{array}{l}\text { CURRENT } \\
\text { LIABILITIES }\end{array}$ & RATIO \\
\hline 2013 & $444,156,523.57$ & $41,181,389.20$ & 10.78 \\
\hline 2014 & $461,499,463.76$ & $60,589,682.56$ & 7.61 \\
\hline 2015 & $363,344,722.59$ & $67,630,244.10$ & 5.37 \\
\hline 2016 & $208,771,533.56$ & $79,014,295.63$ & 2.64 \\
\hline
\end{tabular}

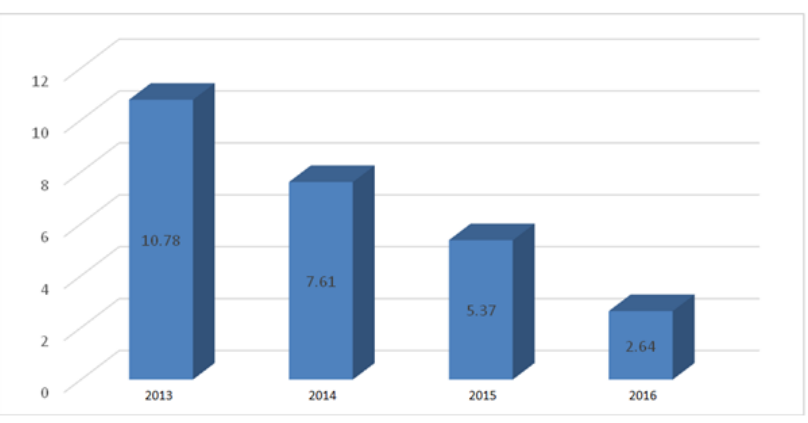

\section{Interpretation:}

The above table shows that the quick ratio. The highest quick ratio is 10.78 in the year of 2013.Then the ratio is decreased in the year of 2014, the ratio value is 7.61.The third highest ratio value is 5.37 in the year of 2015 .

Table -3 Equity Ratio=Shareholders Fund/Total Assets

\begin{tabular}{|l|l|l|l|}
\hline YEAR & $\begin{array}{l}\text { SHAREHOLDERS } \\
\text { FUND }\end{array}$ & TOTAL ASSETS & RATIO \\
\hline 2013 & 0 & $2,268,477,641.36$ & 0 \\
\hline 2014 & $371,180,512.60$ & $2,598,813,204.71$ & 0.14 \\
\hline 2015 & $393,602,427.77$ & $3,037,854,212.95$ & 0.12 \\
\hline 2016 & $409,096,302.76$ & $3,109,422,953.54$ & 0.13 \\
\hline
\end{tabular}

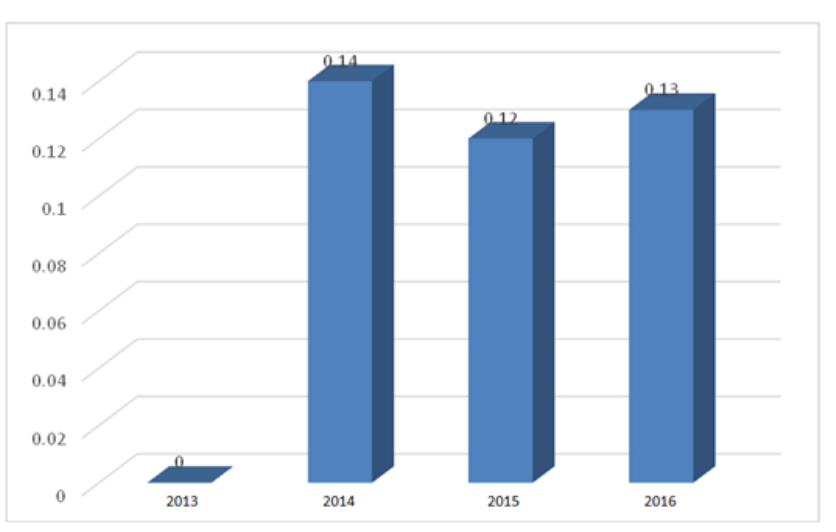

The above table shows that the equity ratio. The highest quick ratio is 0.14 in the year of 2014. Then the ratio is decreased in the year of 2015 , the ratio value is 0.12 .The second highest ratio value is 0.13 in the year of 2016 .

Table -4 Cash Position Ratio=Cash Company Balance +Marketable Securities/Current Liabilities

\begin{tabular}{|l|l|l|l|}
\hline YEAR & $\begin{array}{l}\text { CASH COMPANY } \\
\text { BALANCE+MARKETABLE } \\
\text { SECURITIES }\end{array}$ & $\begin{array}{l}\text { CURRENT } \\
\text { LIABILITIES }\end{array}$ & RATIO \\
\hline 2013 & $424,926,721.54$ & $41,181,329.20$ & 10.31 \\
\hline 2014 & $449,088,955.17$ & $60,589,682.56$ & 7.41 \\
\hline 2015 & $345,502,828.06$ & $67,630,244.10$ & 5.10 \\
\hline 2016 & $183,897,479.06$ & $79,014,295.62$ & 2.32 \\
\hline
\end{tabular}

\section{Interpretation:}

The above table shows that the cash position ratio. The highest cash position ratio is 10.31 in the year of 2013.Then the ratio is decreased in the year of 2014, the ratio value is 7.41. The third highest ratio value is 5.10 in the year of 2015 . Finally the last year ratio value is 2.32 .

Table - 5 Absolute Liquid Ratio=Absolute Liquid Assets/Current Liabilities

\begin{tabular}{|l|l|l|l|}
\hline YEAR & $\begin{array}{l}\text { ABSOLUTE } \\
\text { LIQUID ASSETS }\end{array}$ & $\begin{array}{l}\text { CURRENT } \\
\text { LIABILITIES }\end{array}$ & RATIO \\
\hline 2013 & $424,926,721.54$ & $41,181,389.20$ & 10.31 \\
\hline 2014 & $426,860,722.67$ & $60,589,682.56$ & 7.04 \\
\hline 2015 & $318,525,847.56$ & $67,630,244.10$ & 4.70 \\
\hline 2016 & $169,838,791.51$ & $79,014,295.62$ & 2.14 \\
\hline
\end{tabular}

\section{Interpretation:}

The above table shows that the absolute liquid ratio. The highest absolute liquid ratio is 10.31 in the year of 2013.Then the ratio is decreased in the year of 2014, the ratio value is 7.04.The third highest ratio value is 4.70 in the year of 2015. Finally the last year ratio value is 2.14 .

Table- 6 Proprietary ratio=Proprietors Funds/Total Assets 
International Journal of Recent Technology and Engineering (IJRTE) ISSN: 2277-3878, Volume-8, Issue-2S8, August 2019

\begin{tabular}{|l|l|l|l|}
\hline YEAR & $\begin{array}{l}\text { PROPRIETORS } \\
\text { FUNDS }\end{array}$ & TOTAL ASSETS & RATIO \\
\hline 2013 & $405,456,544.42$ & $2,268,477,641.31$ & 0.17 \\
\hline 2014 & $418,295,486.28$ & $2,598,813,204.71$ & 0.16 \\
\hline 2015 & $435,986,438.62$ & $3,037,854,212.95$ & 0.14 \\
\hline 2016 & $448,348,365.82$ & $3,109,422,953.54$ & 0.14 \\
\hline
\end{tabular}

0.18

0.16

0.14

0.12
0.1

0.1

0.08
0.06

0.04

0.02
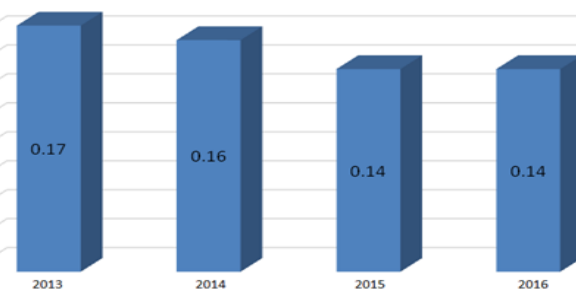

\section{Interpretation:}

The above table shows that the proprietary ratio. The highest proprietary ratio is 0.17 in the year of 2013.Then the ratio is decreased in the year of 2014 , the ratio value is 0.16 . The third highest ratio value is 0.14 in the year of 2015 and 2016.

Table - 7 Comparative Analysis: Comparative Analysis For The Year Ended 2013-2014

\begin{tabular}{|c|c|c|c|c|}
\hline PARTICULARS & 2013 & 2014 & $\begin{array}{l}\text { INCREASE } \\
\text { DECREASE } \\
\text { AMOUNT }\end{array}$ & $\begin{array}{l}\text { INCREASE } \\
\text { DECREASE } \\
\text { AMOUNT }\end{array}$ \\
\hline \multicolumn{5}{|l|}{ ASSETS } \\
\hline \multicolumn{5}{|l|}{ CURRENT ASSETS: } \\
\hline Cash at hand & $26,754,747.00$ & $24,834,429.75$ & $-1,920,317.25$ & -7.18 \\
\hline Cash at bank & $38,885,028.86$ & $46,390,998.62$ & $7,505,969.66$ & 19.30 \\
\hline Balance with other banks & $359,286,945.68$ & $355,635,998.40$ & $-3,651,651.28$ & -1.02 \\
\hline Debtors & $18,463,119.83$ & $33,755,833.53$ & $15,392,713.70$ & 83.37 \\
\hline Advances & $\begin{array}{l}1,242,789,711.4 \\
5\end{array}$ & $\begin{array}{l}1,598,250,518.5 \\
5\end{array}$ & $355,460,807.10$ & 28.60 \\
\hline Bills receivable & $766,682.20$ & $882,907.56$ & $116,225.36$ & 15.16 \\
\hline Prepaid expenses & $2,046,572.54$ & $1,845,382.91$ & $-201,189.63$ & -9.83 \\
\hline Interest receivable & $127,775,486.00$ & $109,798,224.00$ & $-17,977,262.00$ & -14.06 \\
\hline Call money deposits & - & $5,000,000.00$ & $5,000,000.00$ & 0 \\
\hline
\end{tabular}

\begin{tabular}{|c|c|c|c|c|}
\hline Total current ansets( $(\mathrm{A})$ & $\begin{array}{l}1,316,765,2935 \\
6\end{array}$ & $\begin{array}{l}2,176,393,539.2 \\
2\end{array}$ & $359,625,295.65$ & 19.79 \\
\hline \multicolumn{5}{|l|}{ FLUED ASSTS: } \\
\hline Boibing & $3,928,625.95$ & $3,735,057.51$ & $-195,565.44$ & 4.92 \\
\hline MIforniture & $5,349,192,91$ & $6,964,993,52$ & $1,615,900.61$ & 30.21 \\
\hline Vesich & 5.00 & $1,004,018.10$ & $1,004,015.10$ & $20,050,362,00$ \\
\hline Comproser & $3,857,639.23$ & $872,250,33$ & $-2,9535,35390$ & 77.38 \\
\hline Ober abests & $438,573,894.71$ & $409,343,296,03$ & $-28,750,558.65$ & 6.55 \\
\hline Totalfined ausets(B) & $451,170,347.80$ & $422,419,615,49$ & $-28,750,732.31$ & 6.37 \\
\hline Total asuets $(A+B)$ & $\begin{array}{l}2,265,477,6413 \\
6\end{array}$ & $\begin{array}{l}2,595,313,204.7 \\
1\end{array}$ & $300,305,5635$ & 14.56 \\
\hline \multicolumn{5}{|c|}{ IAEBIITIES AND CAPITAL } \\
\hline \multicolumn{5}{|c|}{ CURRENT HAEIITIES: } \\
\hline Bils payable & 766,65220 & 352,90756 & 116,22535000 & 15.16 \\
\hline Teaterest paysbse & $40,414,707,00$ & $39,706,773,00$ & $19,292,06500$ & 47.74 \\
\hline Total current babilities( $A$ ) & $41,181,359,20$ & $60,539,652.56$ & $19,406,293,35$ & 47.12 \\
\hline \multicolumn{5}{|l|}{ CAPITALSERESERVIES: } \\
\hline Capial & $39,599,770,00$ & $36,763,500,00$ & $2,796,270,00$ & 7.06 \\
\hline Reserves & $336,738,887.06$ & $347,784,823.66$ & $11,025,936,60$ & 32.74 \\
\hline
\end{tabular}

\begin{tabular}{|c|c|c|c|c|}
\hline Ober labihat & $\begin{array}{l}1,350,97,595.1 \\
0\end{array}$ & $\begin{array}{l}2,153,673,19544 \\
9\end{array}$ & $17,200,908,9624$ & 98.76 \\
\hline $\begin{array}{l}\text { Total capinat E } \\
\text { reserves(B) }\end{array}$ & $\begin{array}{l}2,227,295,252.1 \\
6\end{array}$ & $\begin{array}{l}2,535,223,522.1 \\
5\end{array}$ & $\begin{array}{l}14915,634,82538 \\
0\end{array}$ & 85.46 \\
\hline $\begin{array}{l}\text { Total babilities E } \\
\text { capital }(A+B)\end{array}$ & $\begin{array}{l}2,265,477,641.3 \\
6\end{array}$ & $\begin{array}{l}2,595,313,204,7 \\
1\end{array}$ & $330,335,563,35$ & 14.56 \\
\hline
\end{tabular}

\begin{tabular}{|c|c|c|c|c|}
\hline PARTICULARS & 2014 & 2015 & $\begin{array}{l}\text { INCREASE } \\
\text { DECREASE } \\
\text { AMOUNT }\end{array}$ & $\begin{array}{l}\text { INCREASE } \\
\text { DECREASE } \\
\text { AMOUNT }\end{array}$ \\
\hline \multicolumn{5}{|l|}{ ASSETS } \\
\hline \multicolumn{5}{|l|}{ CUREEIT ASSETS: } \\
\hline Cash at hand & $24,834,429.75$ & $23,550,210,60$ & $-1,254,219.13$ & -5.17 \\
\hline Cash at bant: & $46,390,998.62$ & $44,660,524.43$ & $-1,750,474,09$ & -3.73 \\
\hline Balace whe ober banks & $355,635,998,40$ & $250,315,112,53$ & $-105,310,131.57$ & -29.61 \\
\hline Debsors & $33,755,833.53$ & $43,677,307,93$ & $9,915,474.40$ & 2937 \\
\hline Á́rases: & $\begin{array}{l}1,395,250,5185 \\
5\end{array}$ & $\begin{array}{l}1,344,455,737.6 \\
5\end{array}$ & $246,205,219.10$ & 15.40 \\
\hline Bills recenivable & $952,907.56$ & $1,141,567.10$ & $-741,340.46$ & -3596 \\
\hline Prepaid expenses & $1,345,382,91$ & $2,243,587,00$ & $395,204,09$ & 213 \\
\hline Ienterest recenable & $109,798,224,00$ & $124,091,983.70$ & $14,295,799.70$ & 1301 \\
\hline Call mosey deposis & & $\cdot$ & $3,000,00000$ & 10000 \\
\hline
\end{tabular}




\begin{tabular}{|c|c|c|c|c|}
\hline & $3,000,000000$ & & & \\
\hline Total current assets(A) & $\begin{array}{l}2,176,393,539.2 \\
2\end{array}$ & $\begin{array}{l}2,334,136,03099 \\
4\end{array}$ & $157,742,441.72$ & 724 \\
\hline \multicolumn{5}{|l|}{ FLED ASSTS: } \\
\hline Boxbingt & $3,735,057.51$ & $3,551,167,49$ & $-135,390002$ & -4992 \\
\hline Forniture & $6,964,993,52$ & $6,619,448.71$ & $-345,34431$ & -496 \\
\hline Vebiche & $1,004,018.10$ & $1,676,739.60$ & 672,7150 & 67.01 \\
\hline Composer & $872,250,33$ & $1,319,994.15$ & 447,70532 & 3153 \\
\hline Ober assets & $409,343,296,03$ & $690,550,522,06$ & $250,70,75205$ & 65.49 \\
\hline Total fined susets(B) & $422,419,615,49$ & $703,718,182.01$ & $281,298,56553$ & 6559 \\
\hline Total ansetz $(A+B)$ & $\begin{array}{l}2,595,313,204,7 \\
1\end{array}$ & $\begin{array}{l}3,037,354,2129 \\
5\end{array}$ & $439,041,005.24$ & 16.39 \\
\hline \multicolumn{5}{|c|}{ HABIIIIIES AND CAPIILIL } \\
\hline \multicolumn{5}{|c|}{ CUREET HABIITIES: } \\
\hline Bils payable & 352,90756 & $1,141557.10$ & 258,65954 & 2950 \\
\hline Interest payabie & $39,706,775,00$ & $66,455,67700$ & $6,731,90200$ & 1156 \\
\hline Total current habibives(A) & $60,539,652.56$ & $67,650,244.10$ & $7,040,561.54$ & 11.62 \\
\hline \multicolumn{5}{|l|}{ CAPITILSERESERTES: } \\
\hline Copial & $36,763,500.00$ & $35,810,030,00$ & $-933,47000$ & -2.65 \\
\hline Reserves & $347,794,823.66$ & $373,563,319.91$ & $25,778,99625$ & 7.41 \\
\hline Ober labinats & $\begin{array}{l}2,153,675,198.4 \\
9\end{array}$ & $\begin{array}{l}2560,350,11399 \\
4\end{array}$ & $40,174,920.45$ & 1890 \\
\hline
\end{tabular}

\begin{tabular}{|c|c|c|c|c|}
\hline $\begin{array}{l}\text { Total capitat है } \\
\text { reserves(B) }\end{array}$ & $\begin{array}{l}2,536,223,522.1 \\
5\end{array}$ & $\begin{array}{l}2970,223,965.3 \\
5\end{array}$ & $432,000,445.70$ & 17.01 \\
\hline $\begin{array}{l}\text { Total babilities ह } \\
\text { capital(A+B) }\end{array}$ & $\begin{array}{l}2,595,313,204.7 \\
1\end{array}$ & $\begin{array}{l}3,037,354,2129 \\
5\end{array}$ & $439,041,063.24$ & 16.39 \\
\hline
\end{tabular}

\section{RESULTS}

The net benefit expanded in the earlier year 2016, contrasting and 2013, 2014, 2015 net benefits sum.

- The current proportion is high in the time of 2013.The proportion worth is 44.11[13], [15], [17].

- The snappy proportion is high in the time of 2013.The proportion worth is 10.78 .

- The value proportion is high in the time of 2013.The proportion worth is 0.14 .

- The money position proportion is high in the time of 2013.The proportion worth is 10.31 .

- The supreme fluid proportion is high in the time of 2013.The proportion worth is 10.31 .

- The exclusive proportion is high in the time of 2013.The proportion worth is 0.17 .

- The fixed advantages for investors subsidize proportion is high in the time of 2016.The proportion worth is 1.68.

- The proportion current liabilities to owner's store are high in the time of 2013.The proportion worth is 0.17. [20],[22], [24]
- The speedy proportion is high in the time of 2013.The proportion worth is 10.78 .

\section{DISCUSSIONS}

It is proposed that the Company can build the present record holders from general society. These assets can be used by the Company and increment their pay with no installment important to the present record holders[25],[27],[29]

The Net Profit of the Company in the year 2015 was exceptionally low, which have been is currently expanded in the year 2016. It is recommended to build the net benefit of the Company which would the danger of experiencing shortfall.

The Net Profit, and Total resource are related emphatically the Company ought to hold the equivalent in future[26],[28],[30].

The ventures are made by the Company was primarily in government protections with low income. So the Company should focus is contributing high yielding protections for acquiring exceptional yield.

\section{V.CONCLUSION}

The examination demonstrates that the Company's presentation is attractive. In some territory they are inadequate in Companying position. In the event that they improve their client administration and innovation they will concoct the standard level[31],[33]. As per the least square technique the Net Profit is required to increment next multi year. So the Company is indicates great element. This investigation uncovers the discoveries and suggestions which would be helpful for the advancement and improvement to the Company.

\section{REFERENCES}

1) BharthVajan R., Ramachandran S.,Psychographic dimensions of training,2016,International Journal of Pharmacy and Technology,V-8,I-4,P-23727-23729

2) Balakrishnan P., Bharthvajan R.,A study on human resource planning in hospitals in Chennai City,2014,International Journal of Applied Engineering Research,V-9,I-22,P-7503-7507

3) Priyadarsini P., Bharthvajan R.,Role of emotional intelligence training programme in reducing the stress of the nurses,2014,International Journal of Applied Engineering Research,V-9,I-22,P-7411-7421

4) Kerinab Beenu G., Bharthvajan R.,Empirical analysis on the cosmetic buying behavior of young women in South India,2014,International Journal of Applied Engineering Research,V-9,I-22,P-7361-7366

5) Balakrishnan P., Bharthvajan R.,Whistling in the wind,2014,International Journal of Applied Engineering Research,V-9,I-22,P-7586-7593

6) Krishnan B., Peter M.,Health hazards of Indian Bpo employee-an alarming issue,2014,International Journal of Applied Engineering Research,V-9,I-22,P-7336-7341

7) Kerinab Beenu G.H., Peter M.,Role of insurance in economic development,2014,International Journal of Applied Engineering Research,V-9,I-22,P-7532-7539

8) Balakrishnan P., Peter M., Priyadarsini P.,Efficiency of safety measures for wellbeing of employees in manufacturing industry,2014,International Journal of 
Applied Engineering Research,V-9,I-22,P-7376-7382

9) Anbarasi M., Praveen Kumar S.,Online sales promotions of herbal products and its effectiveness towards tanisha.com,2019, Indian Journal of Public Health Research and Development,V-10,I-1,P-195-200

10) Anbarasi M., Praveen Kumar S.,Various online marketing and promotions strategies to improve the validation towards the organic products in the pharmaceutical sectors,2019,Indian Journal of Public Health Research and Development, V-10,I-1,P-263-269

11) Loganathan R., Praveen Kumar S.,Grievance handling a key factor for solving issues of employees in an organization,2014,International Journal of Applied Engineering Research,V-9,I-22,P-7483-7491

12) Loganathan R., Praveen Kumar S.,Study on preference of private label brands in super and Hypermarkets,2014,International Journal of Applied Engineering Research,V-9,I-22,P-7327-7335

13) Smitha M., Praveen Kumar S.,Understanding stress and its managementamong the nurses in Chennai city,2014,International Journal of Applied Engineering Research,V-9,I-22,P-7560-7565

14) Kerinab Beenu G.H., Praveen Kumar S.,A study on the investment behavior of Chennai investors in mutual fund schemes,2014,International Journal of Applied Engineering Research,V-9,I-22,P-7520-7525

15) Loganathan R., Praveen Kumar S.,Retention strategies key for organizational productivity,2014,International Journal of Applied Engineering Research,V-9,I-22,P-7443-7447

16) Pavithra J., Ganesan M., Brindha G.,State wise analysis of microfinance sector in India,2016, International Journal of Pharmacy and Technology,V-8,I-4,P-23417-23432

17) Pavithra J., Ganesan M.,A comparative study on microfinance in India and abroad,2016,International Journal of Applied Business and Economic Research,V-14,I-8,P-5471-5476

18) Pavithra J., Ganesan M.,A study on awareness and impact of micro-financial schemes,2016,International Journal of Applied Business and Economic Research,V-14,I-8,P-5449-5460

19) Senthilmurugan P., Pavithra J.,Consumer preference towards organised retailing with reference to Big Bazaar,2014,International Journal of Applied Engineering Research,V-9,I-22,P-7469-7475

20) Senthilmurugan P., Pavithra J.,Implication of social media marketing in growing healthcare industry,2014,International Journal of Applied Engineering Research,V-9,I-22,P-7448-7456

21) Loganathan R., Pavithra J.,Consumer perception towards private label brand over other brands in super markets and hypermarkets,2014,International Journal of Applied Engineering Research,V-9,I-22,P-7355-7360

22) Kerinab Beenu G., Pavithra J.,Tradeâ€"off between liquidity and profitability in logistics industry,2014,International Journal of Applied Engineering Research,V-9,I-22,P-7398-7401

23) Kerinab Beenu G., Pavithra J.,A study on the prospective consumerâ€ $\mathrm{TM}_{\mathrm{S}}$ perception towards utility cars in Chennai city,2014,International Journal of Applied Engineering Research,V-9,I-22,P-7526-7531

24) Pavithra J., Dilli Babu P., Ambuli T.V.,A study on budgetary control at Maruti Service Masters, Chennai,2014,International Journal of Applied Business and Economic Research,V-12,I-2,P-151-161

25) Pavithra J., Dilli Babu P., Ambuli T.V.,A study on customer satisfaction of retro Garments Pvt Ltd, Chennai,2014,International Journal of Applied Business and Economic Research,V-12,I-2,P-381-391

26) Kerinab Beenu G.H., Pavithra J., Senthilmurugan P.,A study on the influence of promotional activities for TATA ARIA among consumers in Chennai,2014,International Journal of Applied Engineering Research,V-9,I-22,P-7572-7578

27) Vijayaragavan S.P.,An investigative expert that's general FBG sensors,International Journal of Mechanical Engineering and Technology,V-8,I-8,PP-1500-1505,Y-2017

28) Vijayaragavan S.P.,Equalization routing protocol for $\mathrm{Wi}-\mathrm{Fi}$ sensor strategy,International Journal of Mechanical Engineering and Technology,V-8,I-8,PP-1662-1666,Y-2017

29) Karthik B., Kiran Kumar T.V.U., Vijayaragavan P., Bharath Kumaran E.,Design of a digital PLL using 0.35 $\hat{\mathrm{I}}^{1 / 4 \mathrm{~m}}$ CMOS technology,Middle East Journal of Scientific Research,V-18,I-12,PP-1803-1806,Y-2013

30) Kanniga E., Selvaramarathnam K., Sundararajan M.,Kandigital bike operating system,Middle - East Journal of Scientific Research,V

31) Jasmin M., Vigneshwaran T., Beulah Hemalatha S.,Design of power aware on chip embedded memory based FSM encoding in FPGA,International Journal of Applied Engineering Research,V-10,I-2,PP-4487-4496,Y-2015

32) Jasmin M.,Optimization techniques for low power VLSI circuits,Middle East Journal of Scientific Research,V-20,I-9,PP-1082-1087,Y-2014

33) Jasmin M., Vigneswaran T.,Fuzzy controller for error control of on - Chip communication,2017 International Conference on Algorithms, Methodology, Models and Applications in Emerging Technologies, ICAMMAET 2017,V-2017-January,I-,PP-1-5,Y-2017

\section{AUTHORS PROFILE}

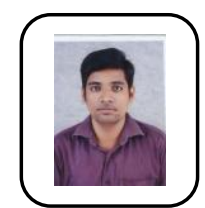

Mr. CS Gowtham Chakravarthy Assistant Professor, Department of MBA, Bharath Institute of Higher Education and Research, Chennai, India.

Dr. S. Praveen Kumar Professor, Department of MBA Bharath Institute of Higher Education and Research, Chennai, India. 